\title{
Cinqüientenário da Faculdade de Medicina de Ribeirão Preto - USP
}

\author{
Anette Hoffmann \\ Docente. Presidente da Comissão de Cultura e Extensão Universitária. Faculdade de Medicina de Ribeirão Preto - USP.
}

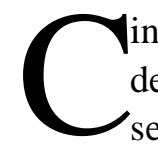
inqüenta anos pouco significam na vida de uma instituição universitária, mesmo antiga das Faculdades de Medicina no Brasil, a da Bahia, fundada em 1808.

Ainda assim, comemoramos a data com a certeza de muitas conquistas. Ao gosto de nosso tempo, exibimos estatísticas invejáveis, que nos garantem um lugar privilegiado no cenário científico internacional. Construímos um conceituado centro formador de profissionais da área médica, que atuam em todos os recantos do País e do Continente. Em outras palavras, cumprimos nosso destino estatutário com competência.

Mas, uma outra história merece ser lembrada e que não se apóia em dados quantitativos, em estatísticas. Não é contada em relatórios nem está documentada. Antes, reside nos corações e mentes de muitos que aqui viveram anos de suas vidas ou que apenas passaram, como aves de arribação. A palavra de um mestre, o olhar de um doente, a dúvida de um aluno, podem ensinar-nos mais sobre o mundo e o homem do que todos os tratados científicos. Como preservar os valores humanísticos, cultivados por tantos mestres, como achar, na urgência do mundo atual, o espaço para vivê-los? Eis o nosso desafio máximo frente ao futuro. Talvez, uma das formas seja manter tantos exemplos vivos em nossa memória e transmiti-los às gerações vindouras. São eles, não as modas de cada época, que mantêm a esperança num mundo melhor, que preservam o espírito utópico da Universidade, sem o qual esta teria fenecido como qualquer empresa.

Ao propor a edição deste número especial da revista Medicina, a Comissão de Cultura e Extensão Universitária confiou a editoração à Profa. Maria de Lourdes Veronese Rodrigues, por conhecer seu espírito empreendedor, seu aguçado senso histórico e seu culto aos valores humanísticos. Ela, de forma correta, confiou a redação dos diferentes capítulos, indistintamente, a docentes, funcionários e alunos, com o propósito explícito de resguardar uma visão dos diferentes segmentos da instituição e uma visão de quem, como protagonista, viveu a história e foi por ela moldado. Tal vivência é que garante a preservação daquele aspecto subjetivo da história de que falávamos anteriormente, daquilo que poderíamos chamar a alma da instituição, que os historiadores, com seus métodos e seus enquadramentos, não logram alcançar. A todos os colaboradores deste número especial da revista nossos agradecimentos.

Agradecemos, também, a sempre presente disponibilidade e atenção da Sra. Maristela Medeiros dos Santos, secretária da Comissão de Cultura e Extensão da FMRP-USP.

Finalmente, esta edição só veio a lume graças ao auxílio concedido pelo BANESPA, através de intermediação feita pela Sra.Elizabeth Paulin, cujo empenho agradecemos. 